\title{
The Effect of Financial Inclusion on Economic Growth and Human Development: A Case Study of the Islamic World
}

Journal of

\section{TANMIYAT AL- RAFIDAIN \\ (TANRA)}

A scientific, quarterly, international, open access, and peer-reviewed journal

Vol. 39, No. 129

March, 2021

(C) University of Mosul | College of Administration and Economics, Mosul, Iraq.

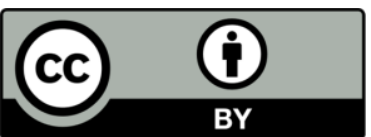

TANRA retain the copyright of published articles, which is released under a "Creative Commons Attribution License for CC-BY-4.0" enabling the unrestricted use, distribution, and reproduction of an article in any medium, provided that the original work is properly cited.

Citation: $\quad$ Talalweh, A. Mohammad, Samarah, A. Wisam (2021). "The Effect of Financial Inclusion on Economic Growth and Human Development: A Case Study of the Islamic World" TANMIYAT AL-RAFIDAIN，39 (129), 185201, https://doi.org/10.33899/tanra.20 21.167800

P-ISSN: 1609-591X e-ISSN: 2664-276X tanmiyat.mosuljournals.com

\author{
Mohammad A. Talalweh, Wisam A. Samarah ${ }^{1 \& 2}$ \\ ${ }^{1 \& 2}$ Faculty of Administration and Economics, Sciences of at Al-Quds Open \\ University- Palestine
}

Corresponding author:Mohammad A. Talalweh, mtalalwa@qou.edu

DOI: https://doi.org/10.33899/tanra.2021.167800

Article History:Received: 1/12/2019; Revised: 30/4/2020; Accepted: 6/1/2021; Published: 1/3/2021.

\begin{abstract}
The purpose of this paper is to determine the effect of financial inclusion on economic growth and human development for Muslim countries. The importance of this topic lies in shedding the light on the crucial and vital role that financial inclusion plays in the development of human capital and thus leading to economic growth. An econometric model was developed to estimate this relationship empirically. The data was collected from the World Bank Group for 28 countries. The correlation coefficient was 0.79 , indicating that there is a strong positive correlation between financial inclusion and human development. Nonetheless, the two regression models indicated that financial inclusion is one of the independent variables which affect both economic growth and human development; where a 1 percent increase in IFI will result in both a 0.83 percent increase in GDP per capita and a 0.09 percent increase in HDI. Therefore governments should try to create an environment that promotes an improvement in the quality of financial services which in turn will contribute to sustainable economic development.
\end{abstract}

Keywords

Economic Growth, Financial Inclusion, GDP per Capita, Human Development. 
محمد تلالوة، وسام عدنان سمارة \& \&

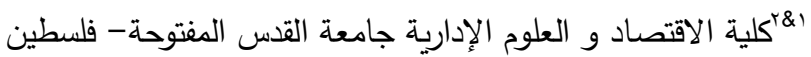

mtalalwa@qou.edu، المؤلف المراسل: محمد تلالوة

DOI: https://doi.org/10.33899/tanra.2021.167800

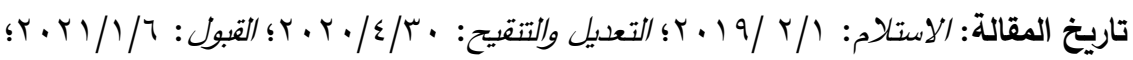

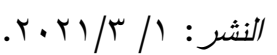

المستخلص

هدفت هذه الدراسة إلى معرفة اثر الثمول المالي على الندو الاقتصادي و تندية الموارد البشرية في

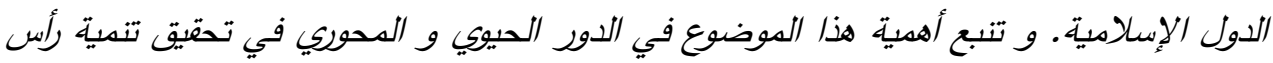
المال البثري مدا بياهم في تحقيق التنمية الاقتصادية. اعتمدت الدراسة على تطوير ندونجان

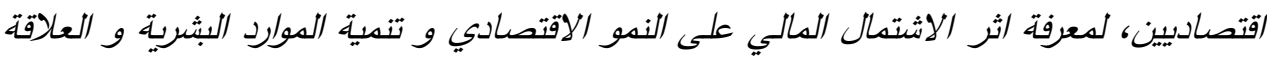
بييهها . وتكونت عينة الدراسة من ثماني وعشرون دولتة من الدولالإسلامية،مدن تتوفر لديهن بيانات

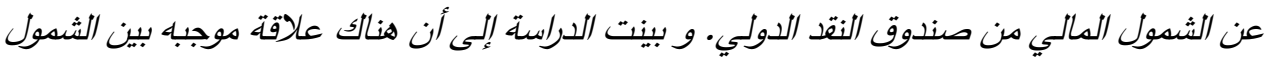

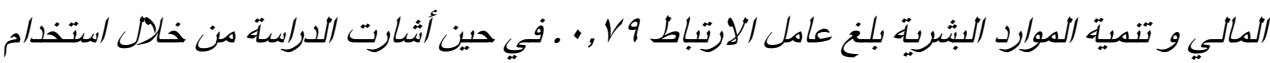

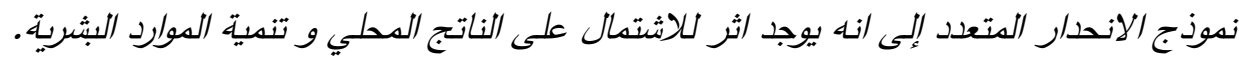

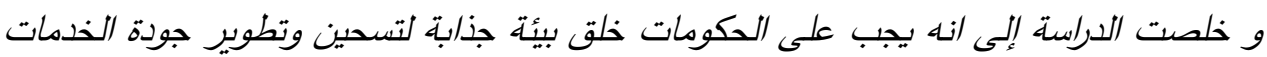
المالية التي ستساهم في تحقيق التندية الاقتصادية المستدامة.

الكلمات المفتاحية النمو الاقتصادي، الاشتمال المالي، الناتج المحلي الإجمالي للفرد،التنمية البشريـة.

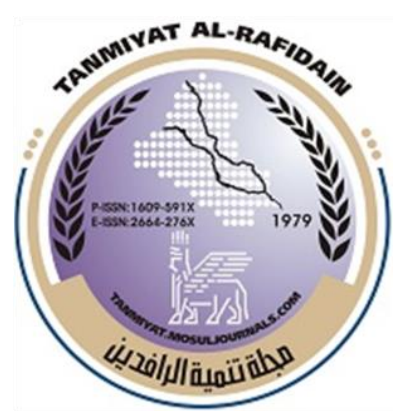

همبة

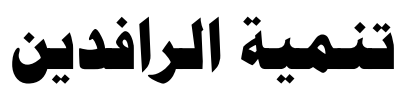

(TANRA) مفتوحة الوصول، محكمة.

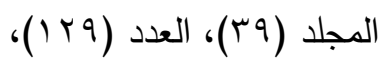

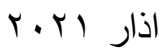

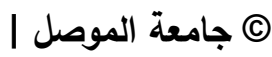
كلية الإدارة والاقتصاد /الموصل، العراق.

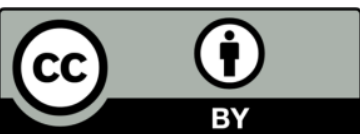

تحتفظ (TANRA) بحقوق الطبع والنشر للمقالات

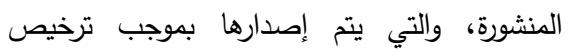
\lrcorner (Creative Commons Attribution) (CC-BY-4.0)

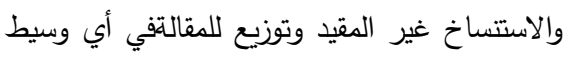
نقل، بشرط اقتباس العمل الأصلي بثكل صحيح. الاقتباس:تلالوة، محد،سمارة، وسام

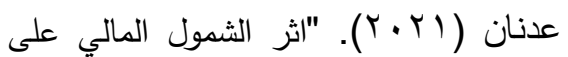
النمو الاقتصادي و تتمية الموارد البشرية :

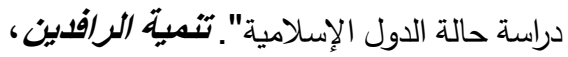

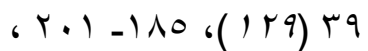
https://doi.org/10.33899/tanra.20 21.167800

P-ISSN: 1609-591X e-ISSN: 2664-276X tanmiyat.mosuljournals.com 


\section{Introduction}

Access to financial services plays a fundamental role in sustainable development. Financial inclusion provides the poor with financial services that will ease expenditures and provide protection against the weaknesses in the financial systems such as insurance against sickness, theft, and unemployment. This financial inclusion of the poor will increase their ability to save, borrow, and invest in entrepreneurship projects. Financial inclusion is vital to underrepresented sectors of society such as women, the poor, and youth in developing countries. Thus this is why financial inclusion had gained substantial interest in the last few years and it was one of the goals that were set to improve the lives of the poor (Demirguc-kunt, Klapper, \& Dinger, 2017). In developing countries, most of the poor citizen's transactions are carried out through the informal sector. Thus they engage in savings, borrowing, and credit transactions through unofficial channels. This is why financial inclusion was proposed for the poor and less fortunate in the official and formal financial system. This will allow them to benefit from the different financial services offered (Consultative Group to Assist the Poor (CGAP), 2011).

Financial Inclusion is defined as "a process that ensures ease of access, availability, and usage of the formal financial system for all members of an economy" (Sarma, 2008). This definition includes several dimensions most importantly accessibility, availability, and usage of the formal financial system. Financial Inclusion was also described as the "share of the population who use financial services" (Ben Naceur, Barajas, \&Massara, 2015). This definition allows for comparison across countries.

The definition was further developed to mean the ease of access and availability of financial services to all citizens, the ability to benefit from utilizing the financial services through encouragement by managing their financial resources, granting credit and insurance against the other, and money transfer services. This will in turn limit the engagement in the informal sector (Demirguckunt, Klapper, \& Dinger, 2017).

The level of financial inclusion varies across counties and is dependent on both the level of income and neighborhood. The degree and amount of utilization of financial services are also dependent on the level of income. The amount of utilization is twice as much in middle-income counties compared to low-income countries. The East Asian and Pacific region is the only region in the world where the average widening of the area for the usage of financial services exceeds the world average. Nonetheless, this average decreases in the Middle East and North Africa region and south of the Great Saharan Desert.

Financial inclusion had gained increasing attention in the past few years from policymakers in both developed and developing countries. It was even included in the sustainable development indicators. Thus financial inclusion leads to an improvement in the standard of living and sustainable economic and social development. In other words, financial inclusion will lead to an increase in the amount of leisure for the nation's citizens. To measure the amount of leisure of a nation, the Human Development Index (HDI) was developed by the United Nations

TANMIYAT AL-RAFIDAIN (P-ISSN: 1609-591X; E-ISSN: 2664-276X) تنمية الرافدين 
for Development Programs (UNDP). This index is used to rank the countries based on the United Nations (UN) reports (United Nations Development Programme , 2011).

The purpose of this paper is to determine the effect of financial inclusion on both economic growth and human development in the Muslim world. The paper will look at the status of financial inclusion in the Middle East, Africa, the Far East, and the former Soviet Union republics. The paper will test two main hypotheses, the first is whether financial inclusion has a significant and positive effect on the Gross Domestic Product (GDP) per capita -economic growth- for the Muslim countries and the second tests the possibility if financial inclusion has a significant and positive effect on human development in the Muslim World. The importance of this paper lies in the fact that it will determine if financial inclusion -which is a new topic- have a positive effect on the GDP per capita. The existence of such a cause and effect relationship can be the answer to a more stable Muslim world, and thus drifting the Islamic countries away from a Volatility, Uncertainty, Complexity, and Ambiguity (VUCA) environment (Samarah\&Tuncay, 2020). So this paper will attempt to solve the research problem can the banks through financial inclusion aid all these countries in boosting economic growth and human development to drift away from a VUCA environment and creating a more stable and prosperous Muslim World?

We will measure economic growth by the GDP per capita. We will also take a look at the Human Development Index (HDI), for the selected countries. This index is based on the Health Index (HI), Education Index (EI), and Income Index (II). The value of the HDI is calculated by finding the mean of the three indexes (Todaro \& Smith, 2015). Meanwhile, Financial Inclusion (FI) is measured using the following three categories:

1. Penetration: The more the financial system is penetrated the more it includes the different categories of the society. This indicator is measured by calculating the percentage of individuals 15 years and older who own a bank account in a particular country. Here we consider that owning a bank account is the first step in benefiting from the financial services.

2. The availability of banking services: the more the availability of the banking services the greater is the number of people included. This indicator is measured for a particular country by the number of commercial bank branches for every 100,000 adults, and the number of ATMs available for every 100,000 adults in a particular country.

3. Usage of financial services is measured by the percentage of adults that have engaged in saving transactions in a formal financial institution within the past 12 months in a particular country; and the percentage of adults engaged in borrowing from an official financial institution within the past 12 months.

(Sarma, 2008) (Sarma, 2012)

The World Bank had adapted its measurement of financial inclusion, where it covers the following dimensions:

TANMIYAT AL-RAFIDAIN (P-ISSN: 1609-591X; E-ISSN: 2664-276X) تنمية الرافدين 
The first dimension is the usage of bank accounts. This dimension is measured by the following:

1. Calculating the percentage of adults having a bank account in an official or formal financial institution such as banks, post offices, and small financing institutions. The purpose of personal or business accounts. The way to access the accounts such ATM or availability of branch.

The second dimension is the savings. This is measured by

1. Calculating the percentage of adults that engaged in saving activities in an official or formal financial institution within the past 12 months,

2. Calculating the percentage of adults who engaged in savings activities within the past 12 months using unofficial, informal, or any person outside the family.

3. Calculating the percentage of adults who engaged in saving activities in the past 12 months through any other institution such as their households.

The third dimension is borrowing, this is measured by:

1. Calculating the percentage of adults engaged in borrowing from a formal or official financial institution within the past 12 months.

2. Calculating the percentage of adults that borrowed from an unofficial or informal institution in the past 12 months including friends and family.

The fourth dimension is expenditures. This is measured by:

1. Calculating the percentage of adults who used an official or formal financial institution to receive their wages or government expenditures within the past 12 months.

2. Calculating the percentage of adults who had either received or sent money transfers from or to family members living in another locality within the past 12 month.

3. Calculating the percentage of adults who used their cell phones to pay a bill, send or receive money transfers.

The fifth dimension is insurance which is measured by:

1. Calculating the percentage of adults who purchase insurance for themselves.

2. Calculating the percentage of adults working in the farming or fishing sectors and purchase insurance to cover their agricultural products and herds against natural disasters, rainfall, and storms (Demirgue-kunt\&Klapper, 2012: 3).

Looking at both measurements of financial inclusion - Sarma $(2008,2012)$ and the World Bank- we notice that they share more or less the same dimensions. Nonetheless, in this study, we will use the index developed by Sarma to conduct our statistical analysis.

The table below shows the GDP per capita, IFI, and HDI for the selected countries for the year 2016. These countries were selected because they are considered developing countries by the World Bank, the data is available -i.e. the World Bank calculated both the IFI and HDI and since the MENA region is an unsuitable region we are interested in whether financial inclusion can aid in ending the Arab Spring.

TANMIYAT AL-RAFIDAIN (P-ISSN: 1609-591X; E-ISSN: 2664-276X) تنمية الرافدين 
The Effect of Financial Inclusion on Economic..........

Talalweh, Samarah

Table 1: The Values of the Financial Inclusion Index and Human Development Index for the Selected Countries for the year 2016

\begin{tabular}{lccc}
\hline \multicolumn{1}{c}{ Country } & $\begin{array}{c}\text { Financial } \\
\text { Inclusion } \\
\text { Index (IFI) }\end{array}$ & $\begin{array}{c}\text { Human } \\
\text { Development } \\
\text { Index (HDI) }\end{array}$ & $\begin{array}{c}\text { GDP Per } \\
\text { Capita (\$) }\end{array}$ \\
\hline Iran & 0.78 & 0.799 & 20200 \\
\hline United Arab emirates & 0.71 & 0.863 & 67700 \\
\hline Kuwait & 0.64 & 0.82 & $33,994.40$ \\
\hline Saudi Arabia & 0.58 & 0.857 & $23,339.00$ \\
\hline Turkey & 0.51 & 0.8 & $9,370.20$ \\
\hline Kazakhstan & 0.46 & 0.79 & $9,812.60$ \\
\hline Lebanon & 0.43 & 0.77 & $8,269.80$ \\
\hline Algeria & 0.38 & 0.74 & $4,114.70$ \\
\hline Uzbekistan & 0.33 & 0.68 & $1,532.40$ \\
\hline Albania & 0.32 & 0.73 & $5,268.80$ \\
\hline Azerbaijan & 0.25 & 0.75 & $4,721.20$ \\
\hline Tunisia & 0.23 & 0.72 & $3,447.50$ \\
\hline Jordan & 0.22 & 0.75 & $4,241.80$ \\
\hline West Bank and Gaza & 0.18 & 0.68 & $3,198.9$ \\
\hline Iraq & 0.17 & 0.672 & $5,834.20$ \\
\hline Egypt & 0.09 & 0.695 & $2,549.10$ \\
\hline Yemen & 0.04 & 0.477 & 944.4 \\
\hline Morocco & 0.31 & 0.669 & $3,237.90$ \\
\hline Syrian Arab Republic & 0.07 & 0.539 & $2,032.60$ \\
\hline Qatar & 0.169 & 0.847 & $68,793.80$ \\
\hline Mauritania & 0.083 & 0.519 & $1,188.80$ \\
\hline Bangladesh & 0.491 & 0.599 & $1,698.30$ \\
\hline Chad & 0.021 & 0.398 & 728.3 \\
\hline Indonesia & 0.503 & 0.7 & $3,893.60$ \\
\hline Afghanistan & 0.125 & 0.491 & 520.9 \\
\hline Malaysia & 0.778 & 0.801 & $11,373.20$ \\
\hline Senegal & 0.364 & 0.506 & $1,522.00$ \\
\hline Pakistan & 0.266 & 0.556 & $1,482.40$ \\
\hline Wor & & & \\
\hline
\end{tabular}

Source: World Bank, website www.worldbank.org; International Monetary Fund; and Sarma's equation was used t calculate IFI for 2016

TANMIYAT AL-RAFIDAIN (P-ISSN: 1609-591X; E-ISSN: 2664-276X) تنمية الرافدين 
Looking at the table above we notice that UAE has an HDI of 0.84 which is considered the highest among the selected countries. Meanwhile, Iran has an IFI of 0.78 which highest among the selected countries.

Nevertheless, Chad has an IFI value of 0.02 and an HDI value of 0.39 which are the lowest among the selected countries. Looking at the GDP per capita, we notice that UAE has the highest value and Yemen has the lowest value.

The rest of the paper will proceed as follows; the next section discusses the relevant literature; financial inclusion from the perspective of economic theory; the methodology will develop our econometric model; the results from the econometric analysis; and finally the conclusion.

\section{Literature Review}

In recent years, laws and policies were implemented to protect the consumers against the risks manifesting from using the innovations in financial services. This is aimed at widening the coverage area of the provision of traditional financial services and making them more accessible. An empirical study had found that per capita income, demographic characteristics, and rule of law were all significant affecting financial inclusion. This was shown through the Ordinary Least Squares regression model (Park \& Mercado, 2016). Thus the rule of law plays a significant role in financial inclusion, i.e. indicating the importance of laws.

Financial inclusion describes access to formal financial services like credit, insurance, and secure saving opportunities. This identified as a critical engine for economic growth (Claessens and Perotti, 2007; Claessens, 2006). Increasing the access of firms and households to various financial services has a strong positive effect on economic growth (Sahay et al., 2015). Financial inclusion contributes positively to economic growth through the creation of valuable small business those results in positive spillover effects on human development indicators including health, education, and reduction of inequality and poverty(Agnello et al., 2012; Park and Mercado, 2015; Nanda and Kaur, 2016).

Financial inclusion is a complex problem. The neoclassical economic theory, new-Keynesian theory, institutional theory, and political economy theory had attempted to examine this phenomenon. The theories can be divided into two main categories based on the key assumptions that they make, they are economic and interdisciplinary. The two assumptions are related to human rationality and the role of the institutions. The first category includes the neoclassical and new-Keynesian theory, meanwhile; the second category includes behavioral economics, institutional theories, political economy theories, poverty and community-based analyses, geographic spatial analyses, and household economy (Buckland, 2012).

Demand-and-supply theory, new institutional economics, and political economy assume that humans are rational and institutions play a major role in explaining financial exclusion. Meanwhile, the new Keynesian economics maintains the human rationality assumption, but are more concerned with the institutional role. The neoclassical so holds onto human rationality and assumes social reality is described as a series of frictionless markets. Behavioral economic theory assumes bounded rationality and is tempted to drop the assumption of human

TANMIYAT AL-RAFIDAIN (P-ISSN: 1609-591X; E-ISSN: 2664-276X) تنمية الرافدين 
rationality and opens the door to sizable social friction in the economy. Finally, the institutional economic theory of savings assumes bounded rationality and a role for the institution (Buckland, 2012).

This paper will discuss the effect of the institutions on human development. Thus we will investigate the effect of financial institutions on human development, i.e. focusing on the role of financial institutions in developing the individual. Hence, we will connect the financial institution to the development of the individual.

Sara (2008) was considered the first to come up with an index for measuring financial inclusion for cross-country analysis. This paper will use Sarma's index to test the effect of financial inclusion on human development. Nonetheless, Goal and Sharma (2017) developed a new index for financial inclusion for India. This index is based on three dimensions that deal with the measurement of the accessibility and usage of financial services(Goel \& Sharma, 2017).

Now let us look at the situation of financial inclusion in the MENA region. Akhtar and Pearce (2010) looked at the microfinance industry in the MENA region and studied the relationship between microfinance, Non-Government Organizations (NGOs), and financial inclusion. They also looked at the Regulatory Structures, the infrastructure in the MENA region, and some approaches and opportunities for financial inclusion in MENA region. The study had concluded that Arab countries suffer from rates of financial exclusion despite certain initiatives from central banks and financial institutions in Egypt, Morocco, Syria, and Yemen (Akhar\& Pearce, 2010)

Pearce (2011) measured the level of financial inclusion in the MENA and was used as an indicator in the world. The study also looked at the effect of the financial crisis on financial inclusion and looked at Islamic microfinance opportunities. He concluded that only 21.3 percent of adults have accents and the use of microcredit is limited (Pearce, 2011).

Wang and Shihader had looked at the situation of financial inclusion in Palestine and compared it to the surrounding countries. It also looked at the different policies and institutions that are implemented by the government to improve the situation of financial inclusion in Palestine and promote economic growth (Wang \& Shihadeh, 2015).

Let us now take a closer look at the relationship between financial inclusion and economic growth. In the 1900s, the belief was an increase in the amount of credit given to the public will increase the number of new businesses generating more income. In turn, this will lead to economic growth and a reduction in income inequality given wealth is distributed equally (Adnan, 2011).

Cagetti and Nardi (2006) demonstrated that better financial intermediation leads to an increase in entrepreneurship activities, an increase in productivity and investment, and a general equilibrium effect that increases wages. Besides, he also showed the importance of the distribution of wealth and the joint distribution of wealth and productivity (Cagetti\&Nardi, 2006).

TANMIYAT AL-RAFIDAIN (P-ISSN: 1609-591X; E-ISSN: 2664-276X) تنمية الرافدين 
Evans and Osi (2017) studied the cause and effect relationship between financial inclusion and GDP per capita in Africa. The paper used the Bayesian VAR model for the World Bank Development Indicators covering the period from 2005 to 2014 for 15 African countries. The findings of the paper had indicated that GDP per capita is positively significant to financial inclusion. Meanwhile, GDP per capita is not significant to financial inclusion.

Sethi and Achary (2018) examined the dynamic impact of financial inclusion on economic growth in both developed and developing countries taking into consideration a large sample. Panel data models such as country-fixed effect, random effect, and time fixed effect regressions were all used to analyze the data. Also, panel cointegration, and panel causality tested the linkage between financial inclusion and economic growth. Panel cointegration was utilized to test the longrun relationship between financial inclusion and economic growth, meanwhile, a panel causality test was performed to determine the direction of causality between financial inclusion and economic growth. The financial inclusion data was taken from Sarma (2012) for the period 2004 to 2010. The empirical results indicated that there is a positive and long-run relationship between financial inclusion and economic growth across 31 countries in the world. The panel causality test indicated that there is bidirectional causality between financial inclusion and economic growth the paper concluded that financial inclusion is one of the main drivers of economic growth.

In this paper, we will look at the cause and effect relationship between financial inclusion on both economic growth and human development for the selected Muslim developing countries. We will add a fourth dimension to Sarma's financial inclusion index equation. Also,we will take a closer look at the effect of financial development on economic growth. The development of the financial sector will create conditions to stimulate economic growth through the forces of supply and demand. The supply forces allow financial development to fuel economic growth, economic growth increases the demand for financial products

\section{Data and Methodology}

The data was taken from the International Monetary Fund and the World Bank for the year 2016 for 28 Muslim countries. This is because these were the only countries that had all the needed indicators for the analysis. Sarma's formula was used to calculate the IFI, as given below

$$
\mathrm{IFI}=\frac{1}{2}\left[\frac{\sqrt{d_{p}^{2}+d_{a}^{2}+d_{u}^{2}}}{\sqrt{1.5}}+\left(1-\frac{\sqrt{\left(1-d_{p}\right)^{2}+\left(.5-d_{a}\right)^{2}+\left(.5-d_{u}\right)^{2}}}{\sqrt{1.5}}\right)\right]
$$

(Sarma,2016.) However, in this paper, we add a fourth dimension to Sarma's index, culture. In the Muslim world, there is a strong belief among a considerable amount of Muslims that banks engage in activities that disobey the orders of God. This is why some Muslims refuse or try to limit their banking activities as much as possible and are not interested in increasing their level of usage. This fact cannot be ignored when talking about financial inclusion. Muslim banks were not able to

TANMIYAT AL-RAFIDAIN (P-ISSN: 1609-591X; E-ISSN: 2664-276X) تنمية الرافدين 
solve this phenomenon completely. Muslim banks are sometimes thought of as the less of two evils. This is why we had decided to tackle this issue and consider it. A variable w was added to Sarma's equation.

$\mathrm{IFI}=\frac{1}{2}\left[\frac{\sqrt{d_{p}^{2}+d_{a}^{2}+d_{u}^{2}}}{\sqrt{1.5}}+\left(1-\frac{\sqrt{\left(1-d_{p}\right)^{2}+\left(.5-d_{a}\right)^{2}+\left(.5-d_{u}\right)^{2}}}{\sqrt{1.5}}\right)\right]-\mathrm{W}$

Where w belongs to the set of Real Numbers and can have the value between 0 and $1-\mathrm{w}$ is bounded between 0 and 1 . The variable $\mathrm{w}$ will shift the financial inclusion index towards the origin, i.e. the minimum point. This is why the larger is the value of $\mathrm{w}$ the more the financial exclusion. If $\mathrm{w}$ equals to one -this means that the whole population believes that banks should be avoided- then IFI Is 0 and banks do not exist. If $w$ equals 0 , then IFI is 1 and everybody is financially included in the banking system. This reflects the power $\mathrm{f}$ culture in the adjusted formula.

The Least Squares regression model will be used to examine the effect of financial inclusion on both economic growth and human development for the Islamic world empirically. The Classical Regression Model is given by the following equation

$\mathrm{Y}=\alpha+\beta \mathrm{X}+\varepsilon$

Where $\mathrm{Y}$ is the dependent variable, $\alpha$ is the $\mathrm{y}$-intercept, $\beta$ is the slope of the line or the rate of change, $\mathrm{X}$ is the independent variable, and $\varepsilon$ is the error term. The $\beta$ coefficient is calculated using the below equation

$$
b=r \frac{S y}{S x}
$$

Where $\mathrm{r}$ is a correlation, $\mathrm{S}_{\mathrm{y}}$ is the standard deviation of they, and $\mathrm{S}_{\mathrm{x}}$ is the standard deviation of $\mathrm{x}$.

The $\alpha$ coefficient is estimated by

$$
a=\bar{y}-b \bar{x}
$$

Where $\bar{y}$ is the mean of, and $\bar{x}$ is the mean of $\mathrm{x}$.

Hence, the following equation is formulated

Where e represents the error term.

$$
y=a+b x+e
$$

The regression model aims to explain the variations in $\mathrm{Y}$ by the variations in $X$, where the $X$ variable is non-stochastic and cannot be represented by a probability distribution. Nonetheless, this does not imply that $\mathrm{Y}$ is non-stochastic because the $\mathrm{Y}$ variable is dependent on both $\mathrm{X}$ and the error term (Samarah, 2016).

The beta coefficient represents the slope of the linear regression line or the rate of change. Thus it shows how much $\mathrm{Y}$ will increase by when $\mathrm{X}$ increases by one. Meanwhile, the error $\varepsilon$ measures the level of disturbance, it measures the difference between the actual and predicted y values. In other words, we can think

TANMIYAT AL-RAFIDAIN (P-ISSN: 1609-591X; E-ISSN: 2664-276X) تنمية الرافدين 
of the $\mathrm{X}$ variable as a signal and the error term as a noise. Thus the error term is disrupting the explanatory variable (Samarah, 2016).

The simple regression model is expanded by adding more explanatory variables; this will increase the accuracy of the model and further explains the variations in the $\mathrm{Y}$ variable. This makes the model more powerful. The multiple regression model is represented by the following equation.

$\mathrm{Y}=\alpha+\beta_{1} X_{1}+\beta_{2} X_{2}+\ldots+\beta_{n} X_{n}+\varepsilon$

Where $\mathrm{Y}$ is the dependent variable; $\alpha$ is the $y$-intercept; $\mathrm{X}_{1}, \mathrm{X}_{2}, \ldots, \mathrm{X}_{\mathrm{n}}$ are the independent variables; $\beta_{1}, \beta_{2}$, and $\beta_{\mathrm{n}}$ are the coefficient of the $X$ variables; $€$ is the error term.

To allow the regression model to take into consideration qualitative variables, the concept of dummy variables will be introduced. A dummy variable is a variable that can account for a quantitative property. This can be done by quantifying the property, 1 to the presence of the property, and 0 for the alternative. Variables that assume such values as 0 and 1 are known as dummy variables. The equation below demonstrates how dummy variables are used

$\mathrm{Y}=\alpha+\beta_{1} \mathrm{D}+\beta_{2} \mathrm{X}+\beta_{3}(\mathrm{DX})+\varepsilon$

where $\alpha$ is the intercept, $\beta_{1}$ is the coefficient of the dummy variable, $\beta_{2}$ is the coefficient of the explanatory variable, $\beta_{3}$ is the coefficient of the product of the dummy variable and explanatory variable, $\mathrm{D}$ is the dummy variable, $\mathrm{X}$ is the explanatory variable, and $\varepsilon$ is the error term. Here $\mathrm{D}$ takes the value of 0 or 1 .

$\beta_{1}$ is called the differential intercept and $\beta_{3}$ is called the differential slope coefficient. The differential slope coefficient shows the change in the slope coefficient due to the presence of the dummy variable. Notice how the introduction of the dummy variable in the interactive or multiplicative form (D multiplied by X), enables us to differentiate between the coefficient of the $X$ variable $\beta_{2}$ and $\beta_{3}$. Thus showing the effect of the dummy variable on the explanatory variable. This is similar to the introduction of the dummy variable in the additive form, which enabled us to differentiate between the intercepts of the two categories. Thus showing the effect of the dummy variable on the intercept.

Now we will develop a model to determine the effect of financial inclusion using the financial Inclusion Index (IFI) on both Gross Domestic Product per capita (GDPPC) and human development for the selected countries. We will start our analysis with the following equation:

$$
Y=A K^{\alpha} L^{\beta}
$$

Where $\mathrm{Y}$ is the output, $\mathrm{A}$ is a parameter that represents the effect of factors other than capital and labor on output, $\mathrm{K}$ is capital stock, $0<\alpha<1,0<\beta<1$, and $\mathrm{L}$ is labor. The above equation is called the Cobb-Douglas production function (Quirk, 1987, p. 151).

The parameter A is known as the Total Factor Productivity (TFP); this is the parameter that the IFI impacts output through entrepreneurs who spur technological advances and innovations shifting the TFP upwards. (Rivera-Batiz, 2002, p. 252).

TANMIYAT AL-RAFIDAIN (P-ISSN: 1609-591X; E-ISSN: 2664-276X) تنمية الرافدين 
Thus an improvement in IFI will motivate more entrepreneurs to emerge -as a result of more people having access to the formal financial system- spurring technology and innovations and thus shifting the TFP upwards, The GDP per capita will be represented by the variable Y, measuring the level of economic growth. The Cobb Douglas production functions if transformed into a linear function by taking the log of both sides, resulting in the following linear function:

$$
\log Y=\log A+\alpha \log K+\beta \log L
$$

Where $\log \mathrm{A}$ is a function of IFI and D:

$\log A=f(I F I, D)$

Where $\mathrm{D}$ is a dummy variable used to measure the fourth dimension -culture. Here we used a dummy variable to measure the fourth dimension. This will give us the following equation:

$\log Y=\beta_{0}+\beta_{1} \log k+\beta_{2} \log L+\beta_{3} \log (I F I)+\beta_{4} D+\varepsilon$

Where $\beta$ s are the parameters to be estimated and $\varepsilon$ represents the random error term.

Now we will develop a second model to determine the effect of Gross Domestic Product per capita (GDPPC) and Financial Inclusion Index (IFI) on the human development index (HDI) for the selected Muslim countries. We will start our analysis with the following equation:

$$
H D I=A G D P P C^{\alpha} I F I^{\beta}
$$

Where $A$ is a parameter that represents the effect of factors other than GDP per capita and IFI on HDI, $0<\alpha<1$, and $0<\beta<1$. Let us now transform the function into a linear function by taking the log of both sides,

$$
\log H D I=\log A+\alpha \log (G D P P C)+\beta \log (I F I)
$$

The dummy variable representing the fourth dimension of the financial inclusion is now added, our econometric model is then given by the following equation:

$\log (H D I)=\beta_{0}+\beta_{1} \log (G D P P C)+\beta_{2} \log (I F I)+\beta_{3} D+\varepsilon$

The year 2016 was selected because it preceded the beginning of the political instability by approximately five years, thus there was enough lag time for the initial spark that caused the political instability to spread around. The political instability allowed the manifestation of the true believer of some of the citizens of each of the Muslim countries to manifest, in most cases, Muslim groups were able to gain more ground and the true believer of some people appeared, of course, had demonstrated that certain portions of the population were in support of laws of Sharia, i.e. they are against the idea of interest rates and thus try to avoid or limit their use of banks as much as possible. This allowed us to evaluate the fourth dimension of the financial inclusion index, where the dummy variable was evaluated on the following bases as 1 was given to countries that experienced any political instability or the manifestation of any Islamic activity. this is due t the simple fact that the emergence $f$ an increase in Islamic activities is a good indication that there is a portion of the population that tritely believe that banks do not abed by the rules of Syria and they should be boycotted. 0 was given to countries that showed no emergence of Islamic activities of any sort. These countries might have citizens

TANMIYAT AL-RAFIDAIN (P-ISSN: 1609-591X; E-ISSN: 2664-276X) تنمية الرافدين 
that do have negative views about banks, but they do not act on it. This is why only one the year 2016 was analyzed, it is more accurate to estimate the fourth dimension of financial inclusion since we allow enough lag time for any ideas to manifest and come into action.

\section{Results}

The Eviews 10 software was used to carry our analysis. We will start our analysis by looking at the distribution of both the IFI and HDI variables. This is done by looking at the descriptive statistics shown in the table below.

Table 2: Descriptive Statistics for IFI and HDI

\begin{tabular}{lll}
\hline Variable Name & IFI & HDI \\
\hline Mean & 0.34 & 0.69 \\
\hline Median & 0.315 & 0.71 \\
\hline Maximum Value & 0.78 & 0.863 \\
\hline Minimum Value & 0.021 & 0.398 \\
\hline Standard Deviation & 0.22 & 0.13 \\
\hline
\end{tabular}

We notice that the mean value for the HDI was 0.69 which is approximately double that of the IFI -0.34 . We also notice that the maximum value and the minimum value of the HDI is 0.863 and 0.398 respectively are both higher than that of the IFI which is 0.78 and 0.021 . Finally, the Standard Deviation of the HDI is 0.13 ; this is lower than that of IFI -0.22 . This means that the values of the HDI for the Muslim countries are closer to the mean, thus they are less spread out when compared to the IFI data spread.

The Pearson correlation coefficient was calculated for the IFI and HDI, and it was 0.78 indicating a strong positive correlation. However, we will expand our analysis and consider the two regression models.

The $\mathrm{f}$ statistic for model 1 is 0.001264 and using an alpha of 0.05 we reject the null hypothesis that all the betas in the model equal to 0 . , using $\alpha=0.05$ and the $\mathrm{p}$-value of the t-test is $0.000,0.1445,0.0161,0.0173$ and 0.8622 for $\beta_{0}$ $\beta_{1}, \beta_{2}, \beta_{3}$ and $\beta_{4}$, respectively. So $\alpha>$ p-value for $\beta_{0}, \beta_{2}$ and $\beta_{3}$ rejecting the null hypothesis and thus the betas are significant. As for $\beta_{1}$ and $\beta_{4}, \alpha<p$-value and we fail to reject the null hypothesis and the betas are not significant. Thus we have the following model:

$$
\log (Y)=12.62+0.47 \log (L)+0.83 \log (I F I)
$$

This model has an $\mathrm{R}^{2}$ of 0.5431 , meaning that 54.31 percent of the variations in the $\mathrm{Y}$ are explained by the model.

Let us now consider the results from the second model where the f-statistic probability value was 0.000000 ; with an $\alpha=0.05$, we reject the null hypothesis, and hence at least one of the betas does not equal to 0 .

Using $\alpha=0.05$ and the $p$-value of the t-test is $0.000,0.000,0.0043$ and 0.6972 for $\beta_{0}, \beta_{1}, \beta_{2}$ and $\beta_{3}$ respectively. So $\alpha>$ p-value for $\beta_{0}, \beta_{1}$, and $\beta_{2}$ hence the betas are

TANMIYAT AL-RAFIDAIN (P-ISSN: 1609-591X; E-ISSN: 2664-276X) تنمية الرافدين 
significant. As for $\beta_{3} \alpha<p$-value, and thus we fail to reject the null hypothesis and the beta is equal to 0 . Therefore, we have the following model:

$$
\log (H D I)=-1.16+0.1 \log (G D P P C)+0.09 \log (I F I)
$$

This model has an $\mathrm{R}^{2}$ of 0.8332 , thus 83.32 percent of the variations in the HDI are explained by the model.

\section{Discussion}

The descriptive statistics shown in Table 2 indicated that the Muslim countries performed better in the HDI when compared to the IFI. Thus the Muslim countries score better in the HDI than the IFI, i.e. the selected countries had a better track record in human development compared to the financial inclusion.

The econometric models did reflect that financial inclusion is one of the independent variables which affect both economic growth and human development; where a 1 percent increase in IFI will result in both a 0.83 percent increase in GDP per capita and a 0.09 percent increase in HDI. The fact that capital was not significant in the first model was somewhat troubling; however, this might be a result of the inaccuracy of the data for the Gross Capital Formation of some countries like Yemen. Since we were only interested in the effect of IFI on the GDP per capita, it did not affect our results.

The correlation coefficient had also indicated that there is a strong positive correlation between HDI and IFI. We had hoped in this paper to capture the effect of the fourth dimension of the IFI nonetheless the dummy variable that represented the fourth dimension was not significant. The availability of better data on the fourth dimension would have given more accurate results. For example, if we knew what was the percentage of the population in each of the Muslim countries that are trying to avoid the use of banks would have been more effective in our analysis.

\section{Conclusion}

Our paper had included that financial inclusion is significant to both economic growth and human development. Thus there is a cause and effect relationship between financial inclusion and both economic growth and human development for the selected countries. Our results support the findings of the vast literature that financial inclusion has a positive effect on economic growth (Sethi and Achary, 2018).

Our results also indicate that banks are playing the role that is expected. This can be attributed to the culture where Islamic banks did reduce the level of distrust towards banks and in some cases eliminating it. This is aiding the spread and outreach of banks and thus expanding their role in influencing both the level of economic growth and human development. Therefore governments should try to create an environment that promotes an improvement in the quality of financial services which in turn will contribute to sustainable economic development.

TANMIYAT AL-RAFIDAIN (P-ISSN: 1609-591X; E-ISSN: 2664-276X) تنمية الرافدين 


\section{References}

Agnello, L., Mallick, S.K. and Sousa, R.M. (2012), "Financial reforms and income inequality", Economics Letters, 116 (3), 583-587.

Acs, Z. (1992). Small Business Economics: A Global Perspective. Challenge, 35 (6), 38-44.

Adnan, N. (2011). Measurement of Financial Development: A Fresh Approach. Qatar: 18th International Conference on Islamic Economics and Finance.

Akhar, S., \& Pearce, D. (2010). Microfinance in the Arab World": The Challenges of Financial Inclusion. Third Edition. Science Research Associates.

Atrash, A. (2014). أثار كارثية على الاقتصاد النلسطيني :الإستطان Ramallah: Madar The Palestinian Forum for Israeli Studies.

Ben Naceur, S., Barajas, A., \&Massara, A. (2015). Can Islamic Banking Increase Financial Inclusion? International Monetary Fund. IMF.

Buckland, J. (2012). Hard Choices: Financial Exclusion, Fringe Banks, and Poverty in Urban Canada. University of Toronto, 26(2), 167-188. University of Toronto Press.

Cagetti, M., \&Nardi, M. (2006). Entrepreneurship, Frictions, and Wealth. Journal of PolitucalEconomy, 114 (5), 835-870.

Carree, M. A., \& Thurik, A. R. (2003). The Impact of Entrepreneurship on Economic Growth. In Handbook of Entrepreneurship Research (pp. 437471). Kluwer Academic Publishers.

Carree, M., \&Thurik, A. (1998). Small Firms and Economic Growth in Europe. Atlantic Economic Jouranl, 26 (2), 137-146.

Claessens, S. (2006), “Access to financial services: a review of the issues and public policy objectives", Oxford University Press on behalf of the World Bank, The World Bank.

Claessens, S. and Perotti, E. (2007), "Finance and inequality: channels and evidence", Journal of Comparative Economics, Vol. 35 No. 4, pp. 748-773.

Consultative Group to Assist the Poor (CGAP). (2011). Financial Access 2009: Measuring Access to Financial Services around the World. Washington, DC.

Deli, F. (2011). Opportunity and Necessity Entrepreneurship: Local Unemployment and Small Firms Effect. Journal of Management Policy and Practice, 12 (4).

Demirguc-kunt, A., Klapper, L., \& Dinger, D. (2017). Financial Inclusion and Inclusive Growt: A Review of Recent Empirical Literature. The World Bank Group. The World Bank Group.

Demirgue-kunt, A., \&Klapper, L. (2012). Measuring Financial Inclusion: The Global Financial Inclusion Index (Global Findex). The World Bank and Bill and Melinda Gates Foundation.

DinabandhuSethi, Debashis Acharya, (2018) "Financial inclusion and economic growth linkage:

Some cross country evidence", Journal of Financial Economic Policy, 10(3), 369385.

TANMIYAT AL-RAFIDAIN (P-ISSN: 1609-591X; E-ISSN: 2664-276X) تنمية الرافدين 
Evans, O., \&Osi, A. R. (2017). Financial Inclusion and GDP Per Capita in Africa: A Bayesian VAR Model. Journal of Economics and Sustainable Development, 8 (18), 44-57.

Goel, S., \& Sharma, R. (2017). Developing a FinacialInclusioin Index for India. Informaton Technology and Quantitative Management, 122, 949-956.

Greene, W. H. (1995). Econometric Analysis (Second Edition ed.). Prentice Hall Inc.

Greene, W. H. (1995). Econometric Analysis, Second Edition. Prentice Hall Inc.

Hanieh, A. A., Abu Elall, S., \& Hasan, A. (2014). Sustainable Development of Stone and Marble Sector in Palestine. Journal of Cleaner Production, 8, 581-588.

Hendry, D. F., \&Juselius, K. (2000). Explaining Cointegration Analysis: Part I. Energy Journal, 21, 1-42.

Higher Council for Innovation and Excellence. (2019, July). Higher Council for Innovation and Excellence. Retrieved January 10, 2019, from Higher Council for Innovation and Excellence: www.hcie.ps

Hoppe, M. (2016). Policy and E,uyt]yt,toyfkpTgobdup[,. Small Business Economics, 46, 13-29.

Hussin, F., \& Ching, C. (2013). The Contribution of Economic Sectors to Economic Growth: The Cases of Malaysia and China. International Journal of Academic Research in Economics and Management Sciences, 2 (2), 36-48.

Kritikos, A. S. (2014). Entrepreneurs and their Impact on Jobs and Economic Growth. IZA World of Labor, 8, 1-10.

Lankauskiene, T., \&Tvaronaviciene, M. (2012). Security and Sustainable Development Approaches and Dimensions in the Globalization Context. Journal of Security and Sustainability Issues, 1 (4), 285-295.

Maddallah, S. A., \& Al-Ajlah, M. (2012). الخصائص والتحديات :ريادة الأعمال في فلسطين. Gaza: Islamic Univeristy of Gaza.

Park, C. Y., \& Mercado, J. R. (2016). Does Financial Inclusion Reduce Poverty and Income inequality in Developing Asia? In In Financial in Asia (Vol. 69, pp. 261-292). Macmillan.

Park, C.Y. and Mercado, R.V. Jr (2015), "Financial inclusion, poverty, and income inequality in developing Asia", No W426, Asian Development Bank, pp. $1-17$.

Pearce, D. (2011). Financial Inclusion in the Middle East and North Africa: Analysis and Roadmap Recommendations. World Bank.

Phillips, P. (1995). Fully Modified Least Squares and Vector Autoregression. Econometrica, 63 (5), 1023 - 1078.

Pisani, D., \& Jacobus, A. (2006). Sustainable Development -Historical Roots of the Concept. Environmental Sciences, 3 (2), 83-96.

Quirk, P. J. (1987). Intermediate Microeconomics (Third Edition ed.). Science Research Associates.

TANMIYAT AL-RAFIDAIN (P-ISSN: 1609-591X; E-ISSN: 2664-276X) تنمية الرافدين 
Raslan, M., \& Abdel Karim, N. (2011). واقع ريادة الأعمال الصغيرة والمتوسطة وسبل تعزيزها Journal of QOU for Administrative and Economic Research and Studies, 23, 43 - 82.

Rivera-Batiz, F. (2002). Democracy, Governance and Economic Growth: Theory and Evidence. Review of Development Economics, 6 (2), 225 - 247.

Sabella, A., Farraj, W., \&Burbar, M. (2014). Entrepreneurship and Economic Growth in West Bank, Palestine. Journal of Developmental Entrepreneurship, 19 (1), 1-15.

Saigh, A. R., \& Ben Zaid, Y. (2015). An International Comparison for Entrepreneurship, Unemployment and Economic Growth for MENA Region. Algerian Studies of Accounting and Financial Review, 1, 1-16.

Samarah, W. A. and Tuncay M., (2020) Interaction between Defense Expenditure and Macroeconomic Indicators: A Case Study of Selected Countries in the MENA Region, Niche Approaches in a Changing World. ksad Publishing, $7-48$.

Samarah, W. A., (2016). The Relationship Between Consumption and Gross Disposable Income and Estimating the Consumption Function for Palestine, IUG Journal of Economics and Business, 24(2), 18-29.

Sarma, M. (2016). Measuring Financial Inclusion Using Multidimensional Data. World Economics. 17(1), 15-40.

Sarma, M. (2012). Index for Financial Inclusion: A Measure of Financial Sector Inclusiveness. Working Paper.

Sarma, M. (2008). Index of Financial Inclusion. Indian Council for Research on International Economic Relations. Indian Council for Research on International Economic Relations.

Todaro, M., \& Smith, S. (2015). Economic Development, 11th Edition (Vol. 51). Boston: Pearson.

United Nations Development Programme . (2011). Human Development Report 2011. United Nations Development Programme (UNDP).

Wang, X., \& Shihadeh, F. (2015). Financial Inclusion: Policies, Statrus, and Challenges in Palestine. International Journal of Economics and Finance, $7(8)$.

World Commission on Environment and Development. (1987). Our Common Future. WCED. 